\title{
Albanian Diaspora across the World
}

\author{
By Joniada Barjaba*
}

The aim of this paper is to advance an understanding of the dynamics and features of the Albanian diaspora and its social, cultural and economic value in relation to Albania's development. The paper gives a fuller account of the Albanian migration and diaspora and shows diaspora's importance to the country's history, development and national affairs. Across the years, diaspora has given a valuable contribution to the protection of individual and social rights, the preservation of language and identity, the protection of the nationwide interests as well as the economic and social development of Albania. Despite its importance, a consensus over definitions of the Albanian diaspora is hardly evident in academic and policy discourses. Overall, the Albanian diaspora is divided into two subsets: the old diaspora and the new diaspora. The old and new diasporas differ in their countries of settlement and migration period. Nowadays, the Albanian diaspora is becoming more connected with the country of origin through permanent, temporary or virtual return. However, the paper suggests that not all diaspora members have the same contribution to the country's development. Looking at the involvement of the old and new diaspora in homeland, it can be argued that the old diaspora has a more important role in nation-building; meanwhile, the new diaspora has a higher willingness to explore entrepreneurial opportunities. That said, with the changing nature of the Albanian diaspora and the technological advancements, the new diaspora is becoming more connected with homeland, especially in business activities when compared to the old diaspora formed during pre-communist times. I conclude that diaspora engagement is an added value for Albania. The key contributions of the paper lie in extending discussions of value of diaspora and in providing a dynamic view of the multiplicity of factors behind diaspora engagement.

Keywords: Albanian Diaspora, Old Diaspora, New Diaspora, Development.

\section{Introduction}

According to the United Nations, there were about 1.2 million Albanians living abroad at the end of 2015, which is equivalent to almost half of the population currently living in Albania (United Nations 2015). Nowadays, with the technological advancements, the Albanian diaspora is becoming more connected with the country of origin through permanent, temporary or virtual return. I examine the Albanian diaspora because of its unique factors such as high migration flows, highly educated professionals, and effective cooperation with diaspora. Scholars confirm that the majority of the Albanian diaspora members are well-educated and overqualified (Barjaba 2015). Diaspora is playing an important role in the economic, social and cultural development of Albania. It has given a valuable contribution to the protection of individual and social rights, the preservation of language and identity, the protection of the

\footnotetext{
"Diaspora Expert, National Agency of Diaspora, Albania.
} 
nationwide interests as well as the economic and social development of Albania. The Albanian communities in the United States, Europe and elsewhere have had a key role in national affairs. Despite its importance and impact, little is known about the Albanian diaspora. To my knowledge there is a lack of literature that would analyze the Albanian diaspora in details and in specific countries. This paper contributes to the literature of the Albanian diaspora by giving a full account of the path of the Albanian diaspora, its active role in the destination countries, and its contribution to the homeland.

The paper is organized into five sections. Section 1 is introductory, setting out the importance of exploring Albanian migration and diaspora. Section 2 proceeds with an overview of the Albanian migration, Albanian diaspora, and diaspora's countries of settlement and migration period. Section 3 presents my study methodology. Section 4 explores the nexus between diaspora and development through distinguishing between old and new diaspora. The final section lays out a set of conclusions and policy recommendations.

\section{Literature Review}

This section revisits two bodies of literature. I provide a synthesis of knowledge in each field and this combined literature review contributes to building up the theoretical foundation of my study. I begin with a brief discussion on Albanian migration, then, I explore two particular subsets of the Albanian diaspora for a better understanding of diaspora's contribution to the country's development.

\section{Overview of Albanian Migration}

Albania is a country with substantial levels of both internal and international migration. However, this paper focuses solely on international migration, as this is the aspect most relevant to my paper. The Albanian migration is best described in three major phases: before 1944, between 1945 and 1990, and mass emigration after the 1990s. There is relatively little information on migration outflows before 1944. Two of the main publications reviewing migration waves during this period are by Barjaba et al. (1992) and Tirta (1999). More specifically, the first flow of Albanian migration took place after 1468, with the death of the Albanian national hero Skanderbeg (see Barjaba et al. 1992, Tirta 1999). The second phase of migration took place during the communist regime. Although Albania's borders were tightly sealed, a small number of citizens managed to cross the borders during this period (Barjaba et al. 1992, Barjaba 2002, 2003). The third migration phase includes the migration flows that occurred with the breakdown of the communist regime that had been in place since 1944. Hundreds of thousands of Albanian citizens left the country to seek more opportunities across the borders. Nowadays, Albanian migration flows continue, but at diminishing rates compared to the past. 
Albanian migration has always been present due to a combination of push and pull factors. The primary push factors for migration during the pre-communist period were mainly political and economic (Carletto et al. 2004, Tirta 1999). Meanwhile, during the communist rule, main factors causing migration flows were primarily political (Barjaba 2004). Lastly, the factors causing the postcommunist migrations have varied from economic factors to dissatisfaction with the corrupted political system, political violence, and difficult living conditions in Albania (King 2003, Albanian Government 2015).

Old vs. New Diaspora

The increase of international migration of Albania has contributed to the formation of Albanian diaspora communities all over the world. When talking about the Albanian diaspora, it is important to highlight some of its key aspects. A consensus over definitions of Albanian diaspora is hardly evident in academic and policy discourses. Overall, the Albanian diaspora consists of i) students; ii) economic migrants; iii) family members of economic migrants; iv) asylum seekers and refugees; and v) unaccompanied minors (Albanian Government, 2015). As mentioned earlier, recently, asylum seekers are a group of increasing size too, even if the reasons for this are somewhat perplexing. Furthermore, the Albanian diaspora is generally seen as divided into two subsets: the old diaspora and the new diaspora. These two groups differ in their countries of settlement and migration period. The following section proceeds with an overview of the diaspora subsets.

\section{$\underline{\text { Old Diaspora }}$}

The old diaspora was formed by the Albanian population groups migrating from Albanian territories to build a better life in various destination countries, to escape the oppression of invaders and later the oppression of the communist regime. The old diaspora consists of three subgroups that migrated at three different periods of time: the old migration flows that took place during the Middle Ages to the mid-nineteenth century; newer migration flows that date from the second half of the nineteenth century to the end of the World War II; and the migration flows during the communist regime. The old diaspora is mainly settled in the United States, Canada, Latin America, Australia, a few countries in Western Europe, and some Eastern European countries, such as Croatia, Romania, Bulgaria, Russia, Ukraine, Slovenia, Bosnia and Herzegovina, as well as Turkey, Egypt, and Syria. Below, I give a brief overview of the old Albanian diaspora, more specifically, the destination countries and diasporas' involvement in homeland.

Diaspora in Italy (Arbëresh community) - The Arbëresh community is an important subset of the Albanian diaspora. They have settled in Italy in the XIV-XV centuries and emigrated mainly due to political and military issues. Their migration flows followed two directions, North and South of Italy. The community that settled in the Northern Italy assimilated; meanwhile, the 
Arbëresh community that settled in Southern Italy managed to preserve the Albanian origin, language, culture and traditions. At the same time, the Arbëresh community has played an important role and has substantially contributed to Italy's history, culture and social life. There are many well-known personalities from the Arbëresh community in Albania and Italy. In Italy, this community is one of the largest ethno-linguistic minorities. Since 1999, the "Arbëresh" language is recognized by the Italian government as the language of the "ethnic and linguistic minority" of the Arbëresh community.

Diaspora in Croatia - The Albanian diaspora moved to Croatia mainly from Kelmendi and Kraja, and settled in Zadar. The resettlement of the people came as a result of the Ottoman oppression and was supported by Pope Clement XI. Albanians who migrated in the early 1750s settled in Hrtkovc and Nikinc. Another group of Albanians from Kosovo and other Albanian lands settled in Croatia during the years of the former Yugoslavia for employment, education or political reasons. In Croatia, Albanians together with four other ethnic minorities have the right to elect a member of parliament.

Diaspora in Bulgaria - The Albanian diaspora in Bulgaria has been present since the $15^{\text {th }}$ century. The migration flows were mainly from Korça, Ohrid, Elbasan, Çermenika, Golloborda, Dibra, and Mati and were a result of persecution from the Ottoman Empire and seasonal employment. Later on, some of these migrants settled in Ukraine and in southern Thrace. Another wave of migration occurred in the XIX-XX centuries and settled in Sofia and other major cities of Bulgaria. Some of the Albanians who settled in Mandritsa were highly involved in the bilateral agreement on minority protection.

Diaspora in Turkey - The largest community of the Albanian diaspora lives in Turkey. Albanians have migrated to Turkey at all times, starting from the $16^{\text {th }}$ century, when Albanian lands were part of the Ottoman Empire. Most of them migrated during the Renaissance and settled in Istanbul and in several cities of Asiatic Turkey. Massive migration flows from Kosovo and other Albanian lands to Turkey occurred in four periods. The first wave occurred after the Lausanne Treaty in 1923; the second wave after the AtaturkStojadinović agreement in 1938; the third wave after Tito-Kyprili secret agreement in 1953; and the fourth wave occurred in the early 1970s. As a result of the above agreements, hundreds of thousands of Albanians were forced to move out of the Albanian territories and settled in Turkey.

Diaspora in Romania - Albanian migration to Romania occurred in the $17^{\text {th }}$ $20^{\text {th }}$ centuries; Albanians settled in this country moved mainly from Southern Albania. The Albanian community in Romania is well-organized and has had a significant contribution to Albania's independence. They are considered an ethnic minority and are represented by a deputy in the Chamber of Deputies of Romania.

Diaspora in Egypt - The diaspora of Egypt consists of two main groups. The first group consists of Albanians that migrated in the early 18th century, after the establishment of Mehmet Ali Pasha as the ruler of Egypt, and settled mainly in Cairo. The second group is the cultural-patriotic diaspora that migrated in the second half of the $19^{\text {th }}$ century and settled in Alexandria (Misir). Most of the Albanians that moved to Egypt pursued military careers. Meanwhile, the diaspora 
in Misir had an influence on the development and spread of the Albanian culture and maintained strong ties with homeland.

Diaspora in Ukraine - Albanians began to migrate to Ukraine in the early $18^{\text {th }}$ century, but the major migration flows occurred in the early $19^{\text {th }}$ century as a way to escape the riots and dangers of the Russian-Turkish wars. Currently, there are more than four thousand people with Albanian origin living in Ukraine. The majority of these people live in the Odessa region.

Diaspora in Slovenia and Bosnia and Herzegovina - The majority of Albanians that left for Slovenia and Bosnia and Herzegovina are from northern Albania, Kosovo, Macedonia and Montenegro. Initially, Albanians moved to these countries during the Ottoman rule for economic reasons. Other migration flows occurred after the Balkan wars as a way to escape the dangerous riots. The number of Albanians in these countries increased during the first decades of the twentieth century. After the Second World War, Albanians of Kosovo settled in Slovenia and Bosnia and Herzegovina as a result of the movements within the former Yugoslavia.

Diaspora in the United States of America - The Albanian diaspora in the United States has given an important contribution to Albania. The earliest group of Albanians arriving in the States is the Arbëresh community and then the economic migrants between the First World War and the Second World War. The third group consists of political migrants that emigrated after the Second World War and the establishment of communist regime in Albania. The fourth flow consists of Kosovar migrants and other parts of the former Yugoslavia who migrated after 1971. The fifth migration movement consists of the Albanian economic migrants who settled in the US after 1990, through the American Lottery and family reunion. Albanian associations in the United States helped in uniting Albanian migrants in the destination country, preserving national identity, opening Albanian schools, publishing and distributing Albanian books, supporting the struggle for freedom and independence and contributing to the autocephaly of the Orthodox Church in Albania. In the early decades of the twentieth century, the Albanian diaspora of the US had Fan S. Noli as a representative in the parliament of Albania.

Diaspora in Argentina - The Albanian diaspora in Argentina is formed by the Arbëresh community. The major migration flow to Argentina took place in the early 20th century and most of them settled in Buenos Aires. Buenos Aires is also the place where the Orthodox Church of Albanians is located.

Diaspora in Syria - Albanians migrated to Syria in the last decades of the Ottoman Empire, in the late $19^{\text {th }}$ and early $20^{\text {th }}$ century, a period during which efforts for Albania's independence were growing. Another migration flow occurred during 1912-1913 when Albanians migrated in order to escape Serbian repression. Albanians are predominantly located in Damascus and in some other major cities of the country. Various Albanian scholars in Syria are known for being highly engaged with different economic, cultural, and political activities.

Diaspora in Russia - Albanians migrated to Russia in the late $19^{\text {th }}$ century by using other transition territories of the former Ottoman Empire. These 
migration flows came as a result of the needs for manpower in various sectors of the economy such as industry, construction, and railways. The majority of the Albanians settled in Caucasus, Irkutsk and Vladivostok. Part of the Albanian diaspora in Russia consists of families created by international marriages. Some Albanians studied and worked in the former Soviet Union and left Albania after the collapse of relations between the two countries.

Diaspora in Australia - The first migration waves of Albanians towards Australia date at the end of the $19^{\text {th }}$ century and expanded in the early decades of the $20^{\text {th }}$ century, after the declaration of Albania's independence. Albanians in Australia have successfully integrated into local labour markets, as well as in social, cultural and sports activities. Additionally, they have given a special contribution in supporting independence of Kosovo.

\section{$\underline{\text { New Diaspora }}$}

The new diaspora is composed of individuals who migrated after the communist regime in Albania. In addition to the migration period, the old and new diasporas differ in their countries of settlement. As discussed earlier, the old diaspora is mainly settled in the United States, Canada, Latin America, Australia, a few countries in Western Europe, and some Eastern European countries. Whereas the greatest concentrations of the new diaspora are in Italy, Greece, Germany, Switzerland, Belgium, Austria and France. Also, a small part of the new diaspora is settled in the countries of the old diaspora.

Diaspora in Italy and Greece - In the early 1990s, Albanians migrated massively to Italy and Greece. The geographic, linguistic, and cultural proximity, and the consumption of Italian television during communism have played an important role in attracting Albanians to this country (Mai 2004). Additionally, many Albanians in the south of the country spoke Greek as there is a Greek minority group living in this area. These factors influenced Albanians' decisions about migration and the destination selection. Over the last three decades, Albanian migrants have successfully integrated into the host countries by being part of the labor market and society and some of them have received citizenship. Among the Albanian migrants there is a large number of individuals who are active participants in the fields of art, culture and sports of the destination countries and homeland. They maintain strong ties with Albania and contribute to the economic, social and political development of the country. These two countries host the largest number of Albanians. By 2015, Greece and Italy both hosted around 450,000 Albanian migrants (United Nations 2015). Besides the neighboring countries, more and more Albanians are now traveling longer distances and settling in various countries such as the USA, Canada, Germany, the UK, and other Western European countries (Albanian Government 2015).

Diaspora in Germany - Albanians from Kosovo and other ethnic-Albanian territories migrated to Germany after 1971, with the abolition of exit visas from the former Yugoslavia. In addition, after 1990, tens of thousands of Albanians migrated from Albania to Germany. Germany is one of the countries where the "embassy" migrants were exiled. Also, Germany was one of the countries which 
gave asylum to many Kosovars during the Kosovo refugee crisis (see Vullnetari 2012, Albanian Government 2015). With the intensification of efforts for Kosovo's independence, these migrants became a community of political migrants that supported the struggle for Kosovo's independence. A survey conducted by King and Gedeshi (2018) on potential migration in Albania confirms Germany as one of the top preferred destination countries. Albanians in this country are well-integrated and continuously preserve Albanian culture and language, promote economic cooperation as well as cultural and educational exchanges between Germany and Albania.

Diaspora in the United Kingdom - The UK is one of the other recently emerging destination countries where the Albanian diaspora is settled. After the establishment of the communist regime in Albania, a small group of former leaders of anti-communist organizations moved to London, but they did not have impactful activities in the host country or Albania. Also, most of the migrants did not arrive in the UK until in the late 1990s, with the collapse of the pyramid savings schemes in 1997 and the Kosovo war in 1999. Some Albanian migrants moved onward from Greece and Italy to the UK to seek better work opportunities (King and Mai 2009). The UK was one of the refugee-hosting countries during the war in Kosovo. Some Albanian citizens claiming to flee the war settled in the UK. The majority of Albanians are concentrated in London and its region (see Vathi and King 2012).

Diaspora in the United States and Canada - The first flow of Albanian immigrants to the United States dates as early as the mid-1880s and to Canada in the early $20^{\text {th }}$ century. However, the scale of migration intensity in these countries became significantly higher in the late 1990s, due to their immigration policies favoring high-skilled and educated migrants. In 2015, the USA hosted around 82,000 and Canada around 13,000 Albanian migrants (United Nations 2015). Albanian diaspora in the United States has a powerful lobby group in the US government in favor of improving development and democracy in Albania and Kosovo. Diaspora in this country preserves and develops cultural traditions and participates in numerous national artistic activities in Albania. Similarly, many talented Albanians have left the country and successfully integrated into the labor market and society in Canada.

Diaspora in Scandinavian countries - The Albanian diaspora in Denmark, Norway and Sweden consists of three main groups: Albanians of Kosovo, Montenegro and Macedonia, who migrated during 1971-1990 as economic migrants; Albanians who migrated from Albania after 1990 as economic migrants; and Albanians who migrated from Kosovo after 1990 to escape Serbian repression. Albanians in Scandinavian countries have integrated into the economic and social life of host countries. They have an active community life and have established cultural, artistic, youth and student associations, radio and television channels, and engage in numerous activities to promote ties and cooperation between the host countries and homeland.

Diaspora in Austria and France - The majority of Albanian migrants settled in these countries after 1990s. Meanwhile, after the establishment of the communist regime in Albania, a small number of former leaders of anti- 
communist organizations had migrated to France. There is a considerable number of Albanian personalities that have worked closely with local universities and academic institutions in the host countries and who have integrated into the countries' economic and social life. The Albanian communities in these two destination countries have established various cultural, artistic and sports associations.

Diaspora in Switzerland - The Albanian diaspora in Switzerland consists of two groups: Albanians from Kosovo and other Albanian territories of the former Yugoslavia who migrated to Germany after 1971 and Albanians from Albania who migrated after 1990. The first group of Albanian diaspora is known for supporting Kosovo's independence. Albanians are currently the fourth largest population in Switzerland. The Albanian diaspora in this country has always been involved in important national and entrepreneurial initiatives.

Diaspora in Belgium - The Albanian diaspora in Belgium was formed mainly after the end of World War II and the establishment of communist regime in Albania. Part of the representatives of anti-communist organizations settled in Belgium and worked against the communist regime in Albania. Following the abolition of visas in 1971 in the former Yugoslavia, Albanians from Kosovo and other republics of the former Yugoslavia, moved to Belgium as economic migrants. The influx of Kosovar migrants increased during the 1990s, as a result of the rise of Serbian repression. There are many Albanian personalities, entrepreneurs, and associations in this country.

\section{Methods of Data Collection}

For this paper both qualitative and quantitative data were used. For gathering qualitative data, I used document review and analysis that involved examination of a variety of papers in order to develop the theoretical framework of the paper. In addition, I conducted several face-to-face interviews with Albanian scholars who helped me verify part of the information related to the old Albanian diaspora. Although my research was mainly based on qualitative approach, quantitative data were also used. With the quantitative data, I was able to get country-specific information related to the Albanian migration and diaspora communities. The data mainly come from census and immigration sources available online. It is important to highlight that papers and data on the Albanian diaspora and its contribution are limited.

\section{Diaspora and Development Nexus}

The impact of migration on development in the origin countries continues to be an open debate. Migration pessimists consider migration as a negative phenomenon undermining the processes of sustained development of migrant sending societies (Frank 1969, Wallerstein 1974, Papademetriou 1985). According to these scholars, migration drains origin countries of their scarce human 
capital. While some scholars and policymakers see the departure of Albanians abroad as a loss, it is important to understand that the engagement of Albanian diaspora can become an added value for Albania as well as for the receiving countries. More specifically, the optimistic perspective treats diaspora as a potential actor in the economic and social development of origin countries (Portes et al. 2002, Saxenian 2002, Zhao 2005, Barjaba and Malaj 2017). In the context of Albania, some studies have examined this topic and have acknowledged that the Albanian diaspora is increasingly important when it comes to the country's development (see Korovilas 1998, Nikas and King 2005, King et al. 2013, Barjaba 2002, 2003, 2011, 2013, 2015, Barjaba and Malaj 2017).

In this paper, I explore the argument that Albanian diaspora has the potential to assist in the development of Albania. However, when talking about diaspora and its contributions, it is important to take into account that not all diaspora members have the same contribution to the country's development. Looking at the involvement of the old and new diaspora in the homeland, it can be argued that the old Albanian diaspora has a more important role in nationbuilding; meanwhile, the new Albanian diaspora has a higher willingness to explore entrepreneurial opportunities and hence has the capacity to contribute to private sector development in Albania. The old diaspora has had a significant contribution to supporting Albania's and Kosovo's independence, preserving national sentiment while abroad, opening schools for learning the Albanian language, publishing and distributing Albanian books, and establishing religious institutions in the destination countries.

Meanwhile, the new diaspora, besides preserving the Albanian language and identity, is highly engaged with entrepreneurial activities too. That said, with the changing nature of the Albanian diaspora and the technological advancements, the new, post-1990s diaspora is becoming more active and connected with the homeland, especially in business activities when compared to the old diaspora formed during pre-communist times. This argument is also aligned with other existing studies that argue that older generations of migrants play a more important role in nation-building and the younger generation has a higher willingness to explore entrepreneurial opportunities and hence have the capacity to contribute to private sector development (Ammassari 2004). Beyond being senders of remittances, Albanian diaspora has the potential to promote entrepreneurship and foreign direct investment. Many of the diaspora members maintain ties with their families and communities in Albania by developing entrepreneurial activities. Some of the Albanian migrant entrepreneurs already have their business in the host country and at the same time are eager to build an economic connection between their new country of acquired residence and their home country.

\section{Conclusions and Policy Recommendations}

This paper has aspired to provide a deeper understanding of the dynamics and features of the Albanian diaspora and its social, cultural and economic 
value in relation to Albania's development. The Albanian migration flows show that Albanian migrants are continuously looking for opportunities to improve their life and employment prospects since the early 1990s. The Albanian diaspora is portrayed as divided into two subsets, the old diaspora and the new diaspora. Nowadays, the Albanian diaspora is becoming more connected with the country of origin. Although the impact of the Albanian diaspora, to some degree, is difficult to assess, I conclude that the engagement of diaspora is an added value for Albania. Diaspora has given a valuable contribution to the protection of individual and social rights, the preservation of language and identity, the protection of the nationwide interests as well as the economic and social development of Albania. However, the old diaspora has a more important role in nation-building; meanwhile, the new diaspora has a higher willingness to explore entrepreneurial opportunities and hence has the capacity to contribute to private sector development in Albania.

My suggested recommendations for the Albanian government are designed to make conditions in Albania more favorable for diaspora members to engage and invest in the country's development. A key priority is to improve the entrepreneurial environment in Albania, with a special focus on increasing the engagement and participation of the Albanian diaspora in the home country. The new diaspora has received more attention by the Albanian government when compared to the old diaspora. Almost all the policies related to Albanian migration have their focus on the new diaspora, neglecting engagement of the old diaspora. In support of the recent diaspora's entrepreneurial initiatives, the Albanian Government has established the Albanian Fund for the Development of Diaspora, which aims to attract investment from the Albanian diaspora in their homeland.

However, the Albanian government can certainly do more to lower the number of existing barriers in the country and create more opportunities for diaspora members to engage in social, economic, and cultural development. The Albanian government and other related actors must have a plan that features a clear approach to diaspora engagement. For instance, the government should consider building and implementing mechanisms to strengthen the country's ties with Albanians abroad, specifically Albanians coming from academia and business communities. In addition, the Albanian government could also take a closer look at the diaspora experiences and policies of countries like Ireland, China, and India in reference to their diasporas and development.

The key contributions of the paper lie in extending discussions of value of diaspora members and organizations and in providing a dynamic view of the multiplicity of factors behind the diaspora engagement with the purpose of making better policies.

\section{References}

Ammassari S (2004) From nation-building to entrepreneurship: the impact of élite return migrants in Côte d'Ivoire and Ghana. Population, Space and Place 10(2): 133-154. 
Albanian Government (2015) Migration Profile 2014. Manuscript submitted for publication. Available at https://www.asp.gov.al/index.php/operacioni-i-dukagjinit /17-shqip/lajmet-e-fundit/8611-profili-i-zgjeruar-i-migracionit-2012-2014.

Barjaba K (2002) Ondate senza ritorno: Scritti e saggi sull'emigrazione Albanese. [Migration waves without return: Writings and essays on Albanian emigration]. Rome: Organizzazione Internazionale per le Migrazioni.

Barjaba K (2003) Shqiptarët. Këta ikës të mëdhenj. [Albanians. Their desire to leave]. Tiranë: Korbi.

Barjaba K (2004) Albania: Looking Beyond Borders. Retrieved from https://bit.ly/2Xk 24FL. [Accessed 28 April 2019].

Barjaba K (2011) As lokalë, as kozmopolitë? Emigrimi si pervojë sociologjike. [Neither local nor cosmopolitan? Emigration as a sociological experience]. Tirana: Toena and UMSH Press.

Barjaba K (2013) Kurthet e Papunësisë. [Unemployment Traps]. Tiranë: EUT Press.

Barjaba K (2015) Migrimi $i$ Varferise. [Migration of poverty]. Tirana: Akademia e Shkencave e Shqiperise.

Barjaba K, Dervishi Z, Perrone L (1992) L'Emigrazione Albanese: spazi, tempi e cause. [Albanian Emigration: spaces, times and causes]. Studi Emigrazione 29(107): 513538.

Barjaba J, Malaj A (2017) Engaging Albanian Communities Abroad: One on One Mentoring. Retrieved from https://bit.ly/2JL1pKi. [Accessed 28 April 2019].

Carletto G, Davis B, Stampini M, Zezza A (2004) International Mobility and International Migration in Albania. ESA Working paper 04-13. Available at http://www.fao.org/3/ ae068e/ae068e00.htm.

Frank AG (1969) Capitalism and Underdevelopment in Latin America. New York: Monthly Review Press.

King R (2003) Across the sea and over the mountains: Documenting Albanian migration. Scottish Geographical Journal 119(3): 283-309.

King R, Mai N (2009) Italophilia meets Albanophobia: paradoxes of asymmetric assimilation and identity processes among Albanian immigrants in Italy. Ethnic and Racial Studies 32(1): 117-138.

King R, Mata CD, Vullnetari J (2013) Migration, development, gender and the "black box" of remittances: comparative findings from Albania and Ecuador. Comparative Migration Studies 1(1): 69-96.

King R, Gedeshi I (2018) New Trends in Potential Migration from Albania. Retrieved from http://library.fes.de/pdf-files/bueros/albanien/15272.pdf. [Accessed 29 May 2019].

Korovilas JP (1998) The Albanian Economy in Transition: The Role of Remittances and Pyramid Investment Schemes. Working Papers in Economics 28. University of the West of England, Bristol.

Mai N (2004) Looking for a more modern life: The role of Italian television in the Albanian migration to Italy. Westminster Papers in Communication and Culture 1(1) :3-22.

Nikas Ch, King R (2005) Economic growth through remittances: lessons from the Greek experience of the 1960s applicable to the Albanian case. Journal of Southern Europe and the Balkans 7(2): 235-257.

Papademetriou DG (1985) Illusions and reality in international migration: Migration and development in post-World War II Greece. International Migration 23(2): 211-223.

Portes A, Guarnizo Le \& Haller WJ (2002) Transnational entrepreneurs: An alternative form of immigrant economic adaptation. American Sociological Review 67(2): 278298. 
Saxenian A (2002) Transnational communities and the evolution of global production networks: the cases of Taiwan, China and India. Industry and Innovation 9(3): 183202.

Tirta M (1999) Migrime të shqiptarëve, të brendshme dhe jashtë atdheut (vitet'40 të shek. $X I X$ - vitet '40 të shek. XX). [International and national migration in Albania (years ' 40 century XIX - years ' 40 century XX)]. Etnografia Shqiptare, 18.

United Nations Department of Economic and Social Affairs (2015) Trends in International Migrant Stock: Migrants by Destination and Origin. Retrieved from http://www.un.org/en/development/desa/population/migration/data/estimates2/estima tesorigin.shtml. [Accessed 28 April 2019].

Vathi Z, King R (2012) Have you got the Britísh?: narratives of migration and settlement among Albanian-origin immigrants in London. Ethnic and Racial Studies 36(11): 1829-1848.

Vullnetari J (2012) Albania on the Move: Links Between Internal and International Migration. Amsterdam: Amsterdam University Press.

Wallerstein I (1974) The Modern World System I, Capitalist Agriculture and the Origins of the European World Economy in the Sixteenth Century. Academic Press, New York.

Zhao F (2005) Exploring the synergy between entrepreneurship and innovation. International Journal of Entrepreneurial Behavior \& Research 11(1): 25-41. 